\title{
SISTEM PEMERITAHAN DAN KEBIJAKAN LUAR NEGERI ARAB SAUDI
}

\author{
Nadia ${ }^{1}$ \\ Email:nadianadirbach@gmail.com
}

\begin{abstract}
The focus of this paper is to discuss the Gulf Arab region, especially Saudi Arabia. This area is known as a region that has a very rich economic source from an abundance of petroleum. There are several countries in the Arab Gulf region, namely, Oman, Qatar, Bahrain, United Arab Emirates, Yemen, Kuwait, Iran and also Saudi Arabia. However, this paper is focused on Saudi Arabia. For the first reason, that Saudi Arabia is the center of the spread of Islam in which there are two holy cities of Mecca and Medina which are the center of the gathering of Muslims worldwide, especially during the Hajj seasons. Second, Saudi Arabia's foreign relations with other countries which are part of Saudi Arabia's foreign policy, which is known to be very close to the anti-terrorist country, namely the United States. The fundamental problem in the discussion of Saudi Arabia lies in the monarchical government system which is still surviving and undergoing a transition from absolute monarchy to constitutional monarchy and Saudi Arabia's foreign relations with other countries that are experiencing unfavorable situations, especially with the United States.
\end{abstract}

Keywords: System, Government, Policy, Saudi Arabia

\begin{abstract}
Abstrak
Fokus kajian tulisan ini adalah membahas tentang kawasan Arab Teluk khususnya Arab Saudi. Kawasan ini dikenal sebagai wilayah memiliki sumber ekonomi yang sangat kaya dari melimpahnya minyak bumi. Ada beberapa negara yang berada pada kawasan Arab Teluk ini yaitu, Oman, Qatar, Bahrain, Uni Emirat Arab, Yaman, Kuwait, Iran dan juga Arab Saudi. Namun, tulisan ini di fokuskan pada Arab Saudi. Dengan alasan pertama, bahwa Arab Saudi adalah merupakan sentral penyebaran agama Islam yang di dalamnya terdapat dua kota suci Mekkah dan Madinah yang menjadi pusat pertemuan umat Islam sedunia khususnya pada musim-musim haji. Kedua, hubungan luar negeri Arab Saudi dengan negara lain yang merupakan bagian dari kebijakan politik luar negeri Arab Saudi yang dikenal sangat dekat dengan negara anti teroris yaitu Amerika Serikat. Masalah mendasar dalam pembahasan tentang Arab Saudi terletak pada sistem pemerintahan monarki yang masih bertahan dan mengalami transisi dari monarki absolut menjadi monarki konstitusional dan hubungan luar negeri Arab Saudi dengan negara lain yang mengalami situasi yang kurang baik khususnya dengan Amerika serikat.

Kata Kunci: Sistem, Pemerintahan, Kebijakan, Arab Saudi
\end{abstract}

\footnotetext{
${ }^{1}$ Fakultas Syariah Institut Agama Islam Negeri Palu
} 


\section{A. PENDAHULUAN}

Islam awal mulanya lahir dan berkembang di Mekkah dan Madinah yang kemudian menyebar hampir keseluruh jazirah Arab pada masa Nabi. Cakupan wilayah dunia Islam pada masa Nabi hanya meliputi yang saat ini kita kenal dihuni oleh negaranegara monarki seperti Arab Saudi, Qatar, Oman, Bahrain, Uni Emirat Arab, Yaman dan Kuwait. Sedangkan pada Sahabat di bawah kepemimpinan Khulafaur Rasyidin, Abu Bakar, Umar, Utsman, dan Ali berhasil mengembangkan Islam ke arah utara. Abu Bakar dalam masa kepemimpinannya telah memperluas Islam hingga ke sebagian Suriah melalui Amru bin Ash dan Irak melalui Khalid bin Walid. Pada masa Umar perkembangan Islam mengalami kemajuan yang luar biasa hingga ke seluruh wilayah Irak, Palestina, dan Mesir. Masa Utsman perluasan wilayah Islam telah mencapai Cyprus dan Tripoli. Dalam kepemimpinan Ali perluasan wilayah Islam hampir tidak memngalami perkembangan yang berarti karena terjadinya konflik internal umat Islam yang secara otomatis menghentikan agresifitas perluasan wilayah Islam. Cakupan wilayah Islam pada masa sahabat telah mencakup wilayah yang cukup luas yang membentang dari Iran hingga sebagian Arab Barat. Wilayahnya meliputi yang saat ini dihuni oleh semua negara Teluk, semua negara Arab Timur dan Iran, negara-negara Delta Nil dan sebagian Arab Barat. ${ }^{2}$

Masa bani Umayyah perluasan Islam mengalami perkembangan yang cukup pesat dibanding sebelumnya, karena pada masa ini perluasan Islam telah meliputi berbagai penjuru terutama Barat, Timur dan Utara. Ke arah Barat, perluasan Islam telah mencapai samudra Atlantik dan menyebrang ke Granada dan kota-kota lainnya di Spanyol dan Bordeuox Perancis. Ke Timur, perluasan wilayah hingga mencakup Irak bagian Timur, Turkistan dan Sindh. Sementara ke wilayah Utara Islam telah mencakup Wilayah konstantinopel (Istanbul), dan Asia kecil. Jika dibandingkan dengan imperium-imperium besar dalam sejarah dunia seperti Romawi dan Persia maka Islam tidak kalah dengan kedua imperium ini. ${ }^{3}$

Setelah masa ini, perluasan wilayah Islam tidak mengalami perkembangan yang signifikan. Seperti halnya imperium-imperium besar lainnya setelah mengalami masa- 
masa kejayaan dan perkembangan pasti mengalami masa kemunduran dan keruntuhan. Demikian pula halnya Islam, setelah runtuhnya kekhalifahan Turki Utsmani yang menjadi simbol kekuatan terbesar umat Islam pada tahun 1924, kekuatan atau kepemimpinan politik umat Islam secara otomatis menjadi terpecah belah ke dalam berbagai kawasan salah satunya adalah kawasan Arab teluk yang di dalamnya dihuni oleh negara-negara Monarki seperti Arab Saudi, Qatar, Bahrain, Yaman, Oman, Uni Emirat Arab, kuwait dan juga Iran.

Arab Teluk adalah satu kawasan yang sangat kaya dengan dengan limpahan minyaknya, sehingga perekonomian negara-negara yang berada di wilayah Arab Teluk mempunyai kekuatan ekonomi yang benar-benar kuat yang dapat dikatakan hampir tidak ada negara-negara Muslim yang berada di kawasan lainnya yang dapat menyamai kekayaan negara-negara ini. Barakah minyak yang dimiliki negara-negara yang berada di kawasan Arab Teluk telah menjadikan negara ini mampu memberikan kesejahteraan secara ekonomis terhadap penduduknya, walaupun sistem pemerintahan negara yang berada di kawasan ini seuruhnya menganut sistem monarki Absolut terkecuali Iran.

Dalam makalah ini, penulis memfokuskan pembahasan pada negara Arab teluk yaitu Arab Saudi. Ada dua alasan mengapa Arab Saudi menjadi pembahasan yang menarik dan perlu untuk dikaji lebih lanjut. Pertama, Arab Saudi adalah negara yang kita kenal menjadi awal mula munculnya Islam yang di bawa oleh Nabi, yang di dalamnya terdapat dua kota suci Mekkah dan Medinah atau yang dikenal dengan istilah Al-Haramain yang menjadi sental penyebaran agama Islam pada masa itu. Ini menjadi dasar bagi kita untuk mengetahui bagaimana sistem pemerintahan Arab Saudi, baik dari segi lembaga eksekutif, legislatif dan yudikatifnya.

Kedua, hal yang menarik dalam membahas Arab Saudi adalah ditinjau dari politik hubungan luar negerinya. Kita ketahui Arab Saudi dalam hubungan luar negerinya awalnya mempunyai hubungan yang erat dengan Inggris pada masa perang dunia I tahun (1901-1930) bahkan mereka sempat membuat kesepakatan atau perjanjian. Akan tetapi, dalam perjalannya perjanjian ini dibatalkan dan Arab Saudi lebih memilih untuk mempunyai hubungan yang erat dengan Amerika Serikat yang dimulai dari raja Abdul aziz ibn Saud hingga sekarang pangeran Abdullah yang menggantikan raja Fahd. Selain mempunyai hubungan yang erat dengan Amerika, Arab 
Saudi juga mempunyai hubungan yang erat dengan negara-negara lain termasuk Indonesia yang tidak hanya berkutat pada hubungan ketenegakerjaannya (TKI dan TKW) tetapi juga persoalan politik.

\section{Kerangka Teori}

Dalam menjelaskan probleamatika tulisan ini, penulis menggunakan teori sistem dan teori hubungan internasional. Menurut David Easton Teori sistem adalah suatu model yang menjelaskan hubungan tertentu antara sub-sub sistem dengan sistem sebagai suatu unit (yang bisa saja berupa suatu masyarakat, serikat buruh, organisasi soial, lembaga swadaya masyarakat dan organisasi pemerintah).

Sedangkan teori sistem menurut Michael Rush dan Philip Althoff menyatakan bahwa gejala sosial merupakan bagian dari politik tingkah laku yang konsisten, internal dan reguler dan dapat dilihat serta dibedakan, karena itu kita bisa menyebutnya sebagai: sistem sosial, sistem politik dan sejumlah sub-sub lainnya. ${ }^{4}$ Teori sistem digunakan untuk menjelaskan sistem pemerintahan Arab Saudi dan hubungan-hubungan yang ada di dalamnya.

Teori hubungan internasional adalah suatu teori yang menjelaskan bagaimana negara-negara berhubugan satu sama lain dalam politik dunia. Dalam teori hubungan internasional pendekatan kebijakan luar negeri selalu menjadi hal yang tidak dipisahkan dan selalu memuat penjelasan tentang kebijakan luar negeri. ${ }^{5}$ Karena, itu dalam melihat hubungan luar negeri Arab Saudi dengan negara lain teori hubungan internasional dengan pendekatan kebijakan luar negeri sangat relefan untuk menjelaskan permasalahan tersebut.

\section{B. PEMBAHASAN}

\section{A. Sistem Pemerintahan Arab Saudi}

Tulisan ini tidak akan menjelaskan tentang sejarah terbentuknya kerajaan Arab Saudi yang dipengaruhi oleh paham Wahabi yang di bawa oleh Muhammad bin Abdul Wahab, dan detail perkembangannya mulai raja pertama dari raja Abdul Aziz Ibn Saud hingga sampai kepada raja Abdullah sekarang yang menggantikan raja Fahd mulai dari

\footnotetext{
${ }^{4}$ Taufik Nurohman. "Teori Sistem David Easton", http://taufiknurohman25.blogspot.com, Diakses tanggal 10 Agustus 2020

5 Jhon T. Ishiyama dan Marijke Breuning (ed), "Ilmu Politik Dalam Paradigma Abad ke-2l",( Jakarta: Kencana, 2013), Jilid l, hlm. 555
} 
tahun 2005 hingga sekarang. Pembahasan makalah ini lebih berfokus pada persoalan sistem pemerintahan Arab Saudi yang ada pada saat ini, dan hubungan luar negeri yang dibangunnya khususnya dengan Amerika dan Indonesia.

Arab Saudi adalah sebuah negara yang berbentuk monarki atau kerajaan. Selain itu, Arab Saudi juga terkenal sebagai negara Islam yang kaya karena memiliki kekayaan alam berupa minyak bumi. Walaupun Arab Saudi merupakan negara Islam, Arab Saudi tidak menggunakan sistem pemerintahan Islam dalam menjalankan roda pemerintahannya. Sistem pemerintahan yang berlaku di Arab Saudi adalah sistem pemerintahan Monarki atau kerajaan. Arab Saudi yang menjalankan sistem pemerintahan monarki dengan beberapa penyesuaian yang diputuskan berdasarkan kondisi negara itu sendiri.

Raja Arab Saudi menyandang gelar sebagai penjaga dan pelayan umat Islam. Pada prakteknya, gelar itu hanya untuk menegaskan posisi moral otoritas raja Arab Saudi yang diklaim untuk dirinya sendiri dalam kaitannya dengan dunia Islam. Sehingga tidak heran bila hukum yang berlaku di Arab Saudi adalah hukum syariat Islam yang berdasarkan pada ajaran agama Islam yang bersumber dari Al-qur'an dan Hadits Nabi. Selain sebagai pelayan umat Islam raja Arab Saudi juga mempunyai peran sebagai kepala negara, perdana menteri, panglima angkatan perang, penjaga dua kota suci atau Khadim Al-Haramain, raja mempunyai wewenang untuk mengangkat dan memberhentikan dewan menteri dan juga raja mempunyai otoritas untuk menfsirkan hukum setelah melalui sejumlah konsultasi dan konsensus. ${ }^{6}$

Banyak negara-negara di dunia yang memandang sistem pemerintahan monarki atau kerajaan yang dijalankan di Arab Saudi merupakan sistem pemerintahan monarki yang kuno dan reaksioner. Bahkan menurut nasionalis Arab Saudi yang revolusioner, Arab Saudi adalah negara buatan yang dibentuk oleh kekuatan kolonial dalam rangka memenuhi kepentingan impreialisme barat. Walaupun pada kenyataannya pandangan sinis tersebut tidak sepenuhnya benar. Sebagai negara yang berbentuk kerajaan dengan sistem pemerintahan yang absolut berdasarkan agama Islam, semua hukum yang berlaku di Arab Saudi juga dibuat berdasarkan syari'at Islam. Sampai pada tuntunan

${ }^{6}$ Ilma Nurhidayati, "sistem pemerintahan saudi arabia” http://ilmakribooo.wordpress.com, diakses tanggal 10 Agustus 2020 
atau panduan raja sebagai kepala pemerintahan dan kepala negara di Arab Saudi juga dibuat berdasarkan ajaran agama Islam. Di Arab Saudi, sistem pemerintahan monarki yang dijalankan adalah sistem pemerintahan monarki yang absolut dimana kekuasaan raja tidak terbatas. Raja juga memegang kekuasaan kepala negara dan kepala pemerintahan. berada di tangan raja. ${ }^{7}$

Dalam negara Arab Saudi walaupun sistem pemerintahannya berdasarkan monarki absolut, negara ini juga memiliki lembaga eksekutif, legislatif dan yudikatif sebagaimana yang ada pada negara-negara yang menganut sistem pemerintahan republik, walaupun lembaga-lembaga tersebut masih berada dalam konrol raja dan belum mempunyai fungsi independensi sebagaimana yang berlaku di negara-negara yang menganut sistem pemerintahan republik yang dalam hal ini termasuk Indonesia.

\section{Cabang Eksekutif}

Pemimpin eksekutif di Arab Saudi adalah rajadan Perdana menteri yaitu Abdullah bin Abdul-Aziz Al Saud sejak 1 Agustus 2005 sampai sekarang. Arab Saudi merupakan salah satu negara di dunia dimana raja memegang dua peran utama yaitu sebagai kepala negara dan kepala pemerintahan. Arab Saudi dipimpin oleh seorang raja yang dipilih berdasarkan garis keturununan atau orang yang diberi kekuasaan langsung oleh raja. Hal ini berdasarkan pasal 5 Basic Law of Government yang menyatakan kekuasaan kerajaan diwariskan kepada anak dan cucu yang paling mampu dari pendiri Arab Saudi, Abdul Aziz bin Abdul Rahman Al-Saud, dimana raja merangkap perdana menteri dan panglima tinggi angkatan bersenjata Arab Saudi. Pada tanggal 20 Oktober 2006 Raja Abdullah telah mengamandemen pasal ini dengan mengeluarkan UU yang membentuk lembaga suksesi kerajaan (Allegiance Institution) terdiri dari para anak dan cucu dari Raja Abdul Aziz Al-Saud. Dalam ketentuan baru, raja tidak lagi memilki hak penuh dalam memilih Putera Mahkota. Raja dapat menominasikan calon Putera Mahkota. Namun, Komite Suksesi akan memilih melalui pemungutan suara. Selain itu, bila Raja atau Putera Mahkota berhalangan tetap, Komite Suksesi akan membentuk

\footnotetext{
${ }^{7}$ Usman Kari Linge Bin Abdul Wahab, "Demokrasi Dalam Pemikiran Politik: Negara Arab Saudi ", http://usmankari.blogspot.com, diakses tanggal 10 Agustus 2020
} 
Dewan Pemerintahan Sementara (Transitory Ruling Council) yang beranggotakan lima orang. 8

Dalam pemerintahan Arab Saudi para dewan Menteri-Menteri ditunjuk langsung oleh raja yang mayoritas berasal dari keturunan dan kaum kerabat raja. Tetapi, semenjak oktober 2003 ada upaya perbaikan terhadap sistem pemilihan ini dengan mengumumkan niat untuk mengadakan pemilu dari setengah anggota wakil pemerintah lokal dan propinsi dan sepertiga dari anggota dewan al-syura dalam waktu empat sampai lima tahun. ${ }^{9}$

\section{Cabang Legislatif}

Di negara Arab Saudi terdapat juga badan legislatif atau disebut Majlis Al-Shura . Raja Fahd Pelayan Dua Kota Suci telah memperkokoh sendi-sendi Syura di Saudi Arabia dengan mengeluarkan sistem yang baru untuk Majelis Syura tertanggal 27/8/1412 H sebagai ganti sistem yang lama tahun $1347 \mathrm{H}$ yang lebih menjadikan raja sebagai penafsir tunggal dalam persoalan undang-undang dan seluruh persoalan sosial lainnya, dan mengesahkan Peraturan Intern Majelis dan ketentuan-ketentuan umum yang menyertainya pada tanggal 3/3/1414 H, kemudian pada Sidang Majelis I menetapkan untuk Majelis seorang ketua dan 60 anggota. Sedang pada Sidang II, Majelis menjadi teridiri dari seorang ketua dan 90 anggota. Pada Sidang III, Majelis berubah terdiri dari seorang ketua dan 120 anggota. Lalu pada Sidang IV terdiri dari seorang ketua dan 150 anggota yang mereka itu berasal dari para ulama, pakar dan spesialis dalam bidangnya Majelis Al-Shura menasihati Raja dan juga Dewan MenteriMenteri tentang isu-isu terkait program-program serta kebijakankebijakan pemerintah. Peran utama majllis ini adalah untuk mengevaluasi, menafsirkan dan memperbaiki hukum pemerintah, hukum kecil, kontrak dan perjanjian internasional..$^{10}$

Pada tanggal 26/6/1426 H = 1/8/2005 M Pelayan Dua Kota Suci raja Abdullah bin Abdul Aziz yang menggantikan raja Fahd, beliau memberikan perhatian yang sangat penuh terhadap Majelis ini dengan mendukung langkah-langkahnya dan memperkuat

\footnotetext{
${ }^{8}$ Angga Diharja Firdaus, "Politik Pemerintahan Arab Saudi", http://diharjaangga.blogspot.com, diakses tanggal 10 Agustus 2020

${ }^{9}$ Usman Kari Linge Bin Abdul Wahab, " Demokrasi Dalam Pemikiran Politik...,

${ }^{10}$ Abu Khansa Salma "Sisi Lain Arab Saudi", http://saudi-tauhid-sunnah.blogspot.com, diakses tanggal 10 Agustus 2020
} 
tujuan-tujuannya sejak beliau menjadi Putra Mahkota, dimana beliau menyampaikan pidato mewakili raja pada permulaan tugas tahunan Majelis dalam Sidang Majelis III dan IB, di samping dukungan yang beliau lakukan kepada Majelis melalui revisi beberapa materi Undang-undang Majelis agar sesuai dengan berbagai perubahan positif yang senantiasa muncul, yang dialami oleh Arab Saudi untuk mewujudkan kesejahteraan bagi rakyatnya.Para elit yang menjadi anggota dalam Majelis yang baru, selama keempat sidangnya, telah menunjukkan kualifikasi mereka dengan menghasilkan pekerjaan-pekerjaan besar dan keputusan-keputusan penting dalam waktu yang cukup singkat. ${ }^{11}$

Dengan adanya lembaga legislatif atau Majlis Al-Shura ini yang kemudian terus dikembangkan oleh raja Fahd maupun raja Abdullah yang memerintah sekarang, Arab Saudi mulai mengalami perkembangan ke arah monarki konstitusional. Kekuasaan atau wewenang raja mulai mengalami pergeseran walaupun lembaga ini prosedur kinerjanya belum sepenuhnya independen karena masih mempertimbangkan pendapat dari raja dan masih berada dalam kontrol raja Arab Saudi.

\section{Cabang Kehakiman atau Lembaga Yudikatif}

Dalam lembaga yudikatif Arab Saudi memiliki lembaga Pengadilan tertinggi di sini adalah Dewan Kehakiman Agung yang membicarakan hal-hal yang disebut oleh Raja. Ia juga merupakan makhamah banding tertinggi dan menimbang banding dan juga merevisi kasus yang melibatkan hukuman mati atau mutilasi yang dijatuhkan oleh pengadilan rendah.Pengadilan Tingkat kedua terdiri dari dua pengadilan yang mendengar rayuan dan yang tertinggi adalah Pengadilan Banding yang terdiri dari lima atau lebih hakim. Pengadilan ini bisa mendengar semua rayuan kecuali kasus-kasus dari badan administratif dan pengadilan atau konflik antara pengadilan syariah rendah dengan pengadilan yang lain.Setelah itu adalah Pengadilan Terbatas yang mendengar kasus-kasus kecil melibatkan hal perdata atau pidana. Sedangkan pengadilan terendah adalah Pengadilan Umum yang mendengar kasus pribadi, sipil , keluarga dan kriminal. ${ }^{2}$

\footnotetext{
${ }^{11} \mathrm{Ibid}$.

${ }^{12}$ Usman Kari Linge Bin Abdul Wahab, " Demokrasi Dalam Pemikiran Politik....,
} 


\section{Administrasi Pemerintahan}

Adapun yang berkaitan dengan Administrasi pemerintahan Arab Saudi, negara ini telah membentuk kabinet yang berkaitan dengan tata pemerintahan pada tahun 1373H/1953M. Majelis ini sekarang mencakup sejumlah departemen yang berkompeten, seperti: Pertahanan, Luar Negeri, Dalam Negeri, Keuangan, Ekonomi dan Perencanaan, Perminyakan dan Pertambangan, Kehakiman, Urusan Islam, Wakaf, Dakwah dan Bimbingan, Pendidikan dan Pengajaran, Pendidikan Tinggi, Kebudayaan dan Informasi, Perdagangan dan Perindustrian, Air dan Listrik, Pertanian, Pekerjaan, Urusan Sosial, Komunikasi dan Teknologi Informasi, Urusan Kota dan Pedesaan, Haji, dan Layanan Sipil..$^{13}$

\section{Pemerintah Daerah}

Ada 13 mintaqah atau daerah propinsi di Arab Saudi dan setiap area adalah dipimpin oleh seorang gubernur yang disebut Amir yang ditunjuk oleh raja. Amir ini pula adalah dibantu oleh seorang wakil gubernur dan juga majelis daerah. Dewan ini terdiri dari ketua-ketua departemen pemerintah tingkat daerah. Disamping itu, acara ini juga dibantu oleh suatu majelis 10 anggota orang-orang ternama di masyarakat masing-masing yang ditunjuk setiap empat tahun. ${ }^{14}$ Adapun mintaqah atau propinsi dalam kerajaan Arab Saudi sekarang terdiri dari 13 propinsi adalah sebagai berikut:

1. Propinsi Daerah Riyadh Ibukota: Riyadh

2. Propinsi Daerah Makkah Al-Mukarramah Ibukota: Mekkah Al-Mukarramah

3. Propinsi Daerah Madinah Al-Munawwarah Ibukota: Madinah Al-Munawwarah

4. Propinsi Daerah Al-Qashim Ibukota: Buraidah

5. Propinsi Daerah Timur Ibukota: Damam

6. Propinsi Daerah Asir Ibukota: Abha

7. Propinsi Daerah Tabuk Ibukota: Tabuk

8. Propinsi Daerah Hail Ibukota: Hail

9. Propinsi Daerah Perbatasan Utara Ibukota: Ar-ar

10. Propinsi Daerah Jizan Ibukota Jizan

11. Propinsi Daerah Najran Ibukota: Najran

\footnotetext{
${ }^{13}$ Angga Diharja Firdaus, "Politik Pemerintahan Arab...,

${ }^{14}$ Usman Kari Linge Bin Abdul Wahab, " Demokrasi Dalam Pemikiran Politik....,
} 
12. Propinsi Daerah Al-Baahah Ibukota: Al-Baahah

13. Propinsi Daerah Al-Juf Ibukota: Sakaka ${ }^{15}$

\section{Pemerintah Lokal}

Ada 178 Dewan pembuangan kota di sini dan setiap acara memiliki anggota antara empat sampai empat belas orang tergantung pada ukuran nya. Kota yang utama seperti Riyadh, Dammam, Jeddah, Mekah dan Madinah memiliki 14 orang anggota dalam pemerintahan lokal. Pemerintah lokal di Taif, AlAhsa, Buraidah, Abha, Hail, Tabuk, Jizan, Bahaah, Najran, Al-Juf dan Wilayah Perbatasan Utara memiliki 12 orang anggota dan majelis di Khamis Mushait, Unaizah, Alkharj, Hafr Al-Baten dan Yanbu ada 10 orang anggota. Pada 2005, separuh dari Dewan ini dipilih melalui cara demokratis yaitu secara pemilu. Sedangkan sisanya lagi ditunjuk oleh pemerintah. ${ }^{16}$

\section{B. Hubungan Luar Negeri Arab Saudi}

Arab Saudi dalam hubungan luar negeri dengan negara-negara lain dan masyarakat internasional bertitik tolak dari prinsip, dasar, dan fakta geografi, sejarah, agama, ekonomi, keamanan, dan politik, serta dalam kerangka utama yang terpenting di antaranya menjaga hubungan baik dengan negara tetangga dan menghindari segala bentuk intervensi dalam urusan dalam negeri negara-negara lain, memperkuat hubungan dengan negara-negara Teluk dan Jazirah Arabia; dan mendukung hubungan dengan negara-negara Arab dan Islam melalui segala hal yang membantu kepentingan bersama dan melindungi permasalahannya. Saudi Arabia mengikuti kebijakan nonblok, dan membangun hubungan kerjasama dengan berbagai negara sahabat, serta memainkan peran aktif melalui berbagai organisasi regional dan internasional. Kebijakan ini digalakkan melalui berbagai lingkup (Teluk, Arab, Islam dan internasional). ${ }^{17}$ Dalam pembahasan ini penulis tidak menjelaskan secara detail mengenai hubungan luar negeri Arab Saudi dengan negara-negara lain, baik yang berada di kawasan Arab Teluk maupun negara-negara Islam secara umum, mengingat luasnya pembahasan tersebut ditambah referensi yang kurang memadai, sehingga

\footnotetext{
${ }^{15}$ Abu Khansa Salma "Sisi Lain Arab....,

${ }^{16}$ Usman Kari Linge Bin Abdul Wahab, " Demokrasi Dalam Pemikiran Politik...,

${ }^{17}$ Angga Diharja Firdaus, "Politik Pemerintahan Arab...,
} 
penulis hanya membahas hubungan luar negeri Arab Saudi yang berkaitan dengan Amerika dan Indonesia.

\section{Hubungan Arab Saudi dengan Amerika}

Jika kita menganalisa dasar hubungan Arab Saudi dengan negara-negara lain yang didasarkan pada berbagai aspek, maka hubungan Arab Saudi dengan Amerika didasarkan pada persoalan ekonomi dan keamanan. Kepentingan Arab Saudi terhadap adalah dalam dua hal, yang pertama persoalan eksplorasi minyak yang ada di Arab Saudi, dan juga persoalan keamanan yaitu Arab Saudi meminta bantuan dari Amerika untuk melindungi kerajaan Arab Saudi dari kekuatan oposisi maupun negara lain yang mencoba merongrong dan meruntuhkan kerajaan Arab Saudi.

Hubungan Saudi-Amerika telah terbentuk pada masa Perang Dunia II, dan pada tanggal 18 Februari 1943, Presiden Amerika Serikat Franklin D. Roosevelt mengumumkan bahwa "membela Arab Saudi adalah sangat vital bagi pertahanan Amerika Serikat," sementara perusahaan-perusahaan minyak Amerika Serikat telah merintis jalan untuk mengukuhkan hubungan ini sepuluh tahun sebelum Roosevelt mengumumkannya, ketika perusahaan Standard Oil of California mendapatkan monopoli untuk pengeboran minyak di wilayah Kerajaan Arab Saudi. ${ }^{18}$

Pada bulan juni 1974 tercapailah kesepakatan yang dikenal dengan istilah jualbeli Militer Amerika-Saudi. Selanjutnya pada waktu itu dibentuk badan bersama Amerika-Saudi untuk kerjasama bidang ekonomi dan bisnis, dan badan kerjasama untuk urusan keamanan. Ketua badan ini dibentuk oleh Menlu Amerika Henry Kissinger seorang Yahudi dan raja Fahd bin Abdul Aziz (yang pada saat itu belum dilantik menjadi raja). ${ }^{19}$

Selama masa 70 tahun, keseimbangan antara perlindungan terhadap rezim Saudi dan aliran minyak dengan harga yang bagus diterapkan. Meskipun hubunganhubungan ini menghadapi beberapa kali ketidaksepahaman satu sama lain dan bahkan ketegangan, namun kasus-kasus demikian tidak terlalu dianggap penting. Namun, belakangan ini keharmonisan tersebut tidak lagi dalam bentuk yang sama seperti

\footnotetext{
${ }^{18}$ Ahmad Malli, "Hubungan Saudi Amerika", http://www.islamtimes, diakses tanggal 10 Agustus 2020

${ }^{19}$ Abu Muhammad Al-Maqdisi, "Saudi di Mata Seorang Al-Qa’idah: Mengkritisi Praktik Hukum Islam di Kerajaan Arab Saudi” Penerjemah Abu Sulaiman , (Solo: Jazera, 2005), hlm 115
} 
sebelumnya, dan lebih cenderung terguncang. Akhir-akhir ini, komplain dari pejabat resmi Saudi terdengar karena kepentingan-kepentingan dari aliansi kuat antara dua negara ini telah terguncang. Hal ini membuat Menteri Luar Negeri AS, John Kerry mengadakan kunjungan darurat ke Riyadh pada bulan November 2013, ia bertemu dengan Raja Abdullah, Menteri Luar Negeri Saud Al Faysal, dan beberapa pejabat resmi Saudi lainnya; namun diragukan apakah Kerry sukses untuk membatasi atau mencegah lebih jauh kemerosotan hubungan dua negara. ${ }^{20}$

Setelah pengumuman tercapainya perjanjian Jenewa 24 November 2013 pada persoalan Nuklir Iran antara kelompok negara P5+1 dan Iran, frustasi Arab Saudi kepada pemerintah Obama mencapai puncaknya. Hal ini bukan semata-mata karena penandatanganan perjanjian, namun lebih pada jalan yang dicapai, bahwa perjanjian itu disiapkan di bawah kerahasiaan total dengan negosiasi melalui jalur samping antara utusan Amerika Serikat dan Iran melalui beberapa tahap, setidaknya delapan bulan sebelum akhirnya penandatanganan perjanjian di Jenewa. ${ }^{21}$

Setelah kepercayaan keluarga Kerajaan Saudi terhadap Washington terguncang dan mengekspresikan perasaan tidak senangnya yang mereka mampu tunjukkan secara maksimum, akankan Saudi berpisah dengan Amerika Serikat? Nampaknya ini tidak akan terjadi, karena Saudi tidak memiliki tempat lain untuk pergi - berdasarkan beberapa analis asal Amerika.Duta besar Amerika Serikat untuk Riyadh tahun 2001-2003, Robert Jordan, mengatakan: "Tidak ada negara di dunia ini lebih mampu memberikan perlindungan pada ladang minyak dan ekonomi mereka selain dari Amerika Serikat, dan Arab Saudi menyadari itu. ${ }^{22}$

\section{Hubungan Arab Saudi dengan Indonesia}

Hubungan Diplomatik Indonesia dan Arab Saudi telah terbina dalam kurun waktu yang cukup lama dan telah menghasilkan banyak bentuk kerjasama yang telah disepakati, hal ini tidak terlepas dari latar belakang Indonesia sebagai Negara berpenduduk muslim terbesar di dunia meskipun secara resmi bukanlah negara Islam. Pola interaksi hubungan internasional kedua Negara juga telah lama berkembang. Hubungan Diplomatik Indonesia-Arab Saudi baru secara resmi tercatat didirikan pada

\footnotetext{
${ }^{20}$ Ahmad Malli, "Hubungan Saudi Amerika...,

${ }^{21} \mathrm{Ibid}$,

${ }^{22} \mathrm{Ibid}$,
} 
tanggal 1 Mei 1950 atau tepatnya 5 tahun setelah Indonesia meraih kemerdekaan dan menjadi Negara yang berdaulat. Awal mula hubungan diplomatik resmi ini sangat terkait dengan usaha rakyat Indonesia untuk mendapatkan kemerdekaan yang selalu mendapat dukungan dan simpati dari Negara-Negara di Timur Tengah khususnya Arab Saudi.

\section{- Kerjasama Politik Indonesia-Arab Saudi}

Dalam kerjasama politik, Indonesia dengan Arab Saudi telah melakukan kerjasama politik pada tanggal 24 November 1970, yaitu dalam bentuk Treaty of Friendship Between the Republic of Indonesia and the Kingdom of Saudi Arabia. (Perjanjian Persahabatan Antara Republik Indonesia dan Kerajaan Arab Saudi). Dalam hal ini kedua negara tidak mengintervensi atau memaksa kehendak politik masingmasing. Karena dalam kerjasama politik umumnya cenderung pada upaya untuk mempererat hubungan bilateral kedua negara berdasarkan sistem politik luar negeri kedua negara. ${ }^{23}$

\section{- Kerjasama Ekonomi Indonesia-Arab Saudi}

Pada 7 Agustus 2003, kedua negara sepakat dalam kerjasama Agreed Minutes yang berisikan butir-butir Kesepakatan di bidang ekonomi dan perdagangan pada Pertemuan Ketujuh Komisi Bersama Antara Republik Indonesia dan Kerajaan Arab Saudi, Jakarta, 6-7 Agustus 2003. Pada tanggal 18 Desember 201l, Delegasi Kemenko Perekonomian Indonesia telah melakukan kunjungan kerja ke Riyadh yang dipimpin oleh Rizal Affandi Lukman, Delegasi RI telah melakukan serangkaian pertemuan dengan Dr. Ahmad Habib, Deputi Menteri Ekonomi dan Perencanaan,Kementerian Ekonomi Arab Saudi. ${ }^{24}$

\section{KESIMPULAN}

Arab Saudi adalah sebuah negara yang berbentuk monarki atau kerajaan. Selain itu, Arab Saudi juga terkenal sebagai negara Islam yang kaya karena memiliki kekayaan alam berupa minyak bumi. Walaupun Arab Saudi merupakan negara Islam, Arab Saudi tidak menggunakan sistem pemerintahan Islam dalam menjalankan roda pemerintahannya. Sistem pemerintahan yang berlaku di Arab Saudi adalah sistem

\footnotetext{
${ }^{23}$ Manuel Marbun, "Hubungan Diplomatik Indonesia Arab Saudi", http://www.slideshare.net, diakses tanggal 10 Agustus 2020

${ }^{24}$ Ibid,
} 
pemerintahan Monarki atau kerajaan. Arab Saudi yang menjalankan sistem pemerintahan monarki dengan beberapa penyesuaian yang diputuskan berdasarkan kondisi negara itu sendiri. Namun pada masa raja Fahd dan sekarang raja Abdullah monarki Arab Saudi telah mengarah kepada monarki konstitusional karena dengan pengembangan Majelis Al-Shura oleh kedua raja tersebut.

Arab Saudi dalam hubungan luar negeri dengan negara-negara lain dan masyarakat internasional bertitik tolak dari prinsip, dasar, dan fakta geografi, sejarah, agama, ekonomi, keamanan, dan politik, serta dalam kerangka utama yang terpenting di antaranya menjaga hubungan baik dengan negara tetangga dan menghindari segala bentuk intervensi dalam urusan dalam negeri negara-negara lain, dan mendukung hubungan dengan negara-negara Arab dan Islam melalui segala hal yang membantu kepentingan bersama. Hubungan luar negeri Arab dengan Amerika didasarkan atas kepentingan ekonomi dalam hal ini adalah minyak dan persoalan keamanan negara. Sedangkan hubungan Arab Saudi dengan Indonesia dibangun atas dasar kesamaan agama dalam hal ini adalah Islam.

\section{DAFTAR PUSTAKA}

Al-Maqdisi, Abu Muhammad, "Saudi di Mata Seorang Al-Qa'idah: Mengkritisi Praktik Hukum Islam di Kerajaan Arab Saudi”, Solo: Jazera, 2005

Burdah, Ibnu, "Islam Kontemporer, Revolusi dan Demokrasi" Malang; Intrans Publishing, 2014

Firdaus, Angga Diharja, "Politik Pemerintahan Arab Saudi", http://diharjaangga.blogspot.com, akses tanggal 10 Agustus 2020

Jhon T. Ishiyama dan Marijke Breuning (ed), "Ilmu Politik Dalam Paradigma Abad ke-2l", Jakarta: Kencana, 2013

Kari Linge Bin Abdul Wahab, Usman, " Demokrasi Dalam Pemikiran Politik: Negara Arab Saudi ", http://usmankari.blogspot.com, akses tanggal 10 Agustus 2020

Malli, Ahmad, "Hubungan Saudi Amerika", http://www.islamtimes, akses tanggal 10 Agustus 2020 
Marbun, Manuel "Hubungan Diplomatik Indonesia Arab Saudi”, http://www.slideshare.net, akses tanggal 10 Agustus 2020

Nurhidayati, Ilma, "sistem pemerintahan saudi arabia" http://ilmakribooo.wordpress.com, akses tanggal 10 Agustus 2020

Nurohman, Taufik, "Teori Sistem David Easton", http://taufiknurohman25.blogspot.com, Diakses tanggal 10 Agustus 2020

Salma , Abu Khansa, "Sisi Lain Arab Saudi”, http://saudi-tauhid-sunnah.blogspot.com, akses tanggal 10 Agustus 2020 